mag. Albert

Mrgole

asistent na

Filozofski fakulteti

in razvojni

sodelavec na ACS

\title{
MLADI V IZOBRAŽEVANJU ODRASLIH
}

\section{Načrtovanje izobraževalnih programov za odpravljanje brezposelnosti mladih}

○

nekoliko nostalgično in poenostavljeno izberemo poglavja, skozi katera so se »socializirali« naši niti ne tako oddaljeni predniki, trčimo na nekaj neogibnih in nespremenljivih mejnikov. Vselej se kot odločilna strategija posameznikovega odraščanja izkaže praksa, povezana s šolanjem, pridobitvijo spričevala in zaposlitvijo. Tako so se doslej kazale možnosti samostojnega življenja in iz njih izhajajoča pridobitev družbenega statusa odraslega. Spomnimo se zgodbe o individualni zaposlitveni karieri pri generacijah, ki so se - ob raznih pozabljenih folklornih običajih odločile vrniti na slovenska tla kapitalizem. Njihova individualna zgodba je bila vpeta $\mathrm{v}$ sistem, ki je deloval, stopnja uspešnosti pa je bila večinoma odvisna od posameznikove "pridnosti «. V mislih imamo seveda sistem, ki je imel v svojem označevalcu nekaj pritiklin socialnega, a je na koncu osemdesetih doživel politično degradacijo. Nadomestil ga je sistem, ki ga določa predvsem tržna logika. V spremenjenih političnih razmerah, ki jih označuje magična beseda tranzicija, ljudje počasi spoznavajo nova družbena razmerja, katerih posledica je tudi izrazito povečanje mladinske brezposelnosti. Zanos generacij, ki so verjele (in še verjamejo) v spremembe na bolje, povezane s spremembo političnega sistema, se je ob učinkih novega družbenega sistema, ki je prizadel perspektivo mlajših generacij, izkazal kot streznitev. Optimistično verovanje staršev $\mathrm{v}$ nasmeh imperialističnih užitkov po vzorcu reklam za kokakolo, ki so mu nasedli prek televizije, se je vrnilo med domače stene kot pesimizem dolgoročne brezperspektivnosti in družbene izključenosti njihovih otrok. $\mathrm{V}$ perspektivi individualnih zaposlitvenih možnosti je bistvo tranzicije $\mathrm{v}$ tem, da je sistem, o katerem smo bili prepričani, da je neuspešen in nefunkcionalen, omogočal uspešno družbeno integracijo, ko pa je postalo verovanje $\mathrm{v}$ »uspešen in organiziran" sistem dominantna ideologija družbenega razvoja, se je kot učinek realnega delovanja sistema pokazala negotovost individualnih zaposlitvenih (in s tem tudi drugih življenjskih) možnosti. Če je bila prej zgodba o uspehu na strani posameznikov, se je zdaj preselila na stran političnega sistema in pustila pri tem naivno verujoče ljudi praznih rok.

Tako mladi, ki čedalje pogosteje in statistično dokaj pomembno sami izstopajo iz šolskega sistema, zapadejo ideološki sodbi, ki v argumentacijo (šolskega) neuspeha vpelje krivdo posameznika. Mnenje o osebni krivdi je toliko uveljavljeno, da vanj verjamejo celo sami osipniki, čeprav se implicitno zavedajo spregleda strukturnih in družbeno institucionalnih razmer, ki šele omogočajo, da individuum nastopi kot dejavni udeleženec. Kakorkoli, sistem se ne ukvarja s takim razmišljanjem, marveč skuša s socialnimi ukrepi omiliti nastali položaj. Vendar socialna stigmatizacija te problematike ne rešuje, zato ostaja kot edina resna alternativa organizacija prilagodljivejših in manj šolsko organiziranih izobraževalnih oblik. O prednostih investicije $\mathrm{v}$ nove izobraževalne pristope za mlade osipnike (čeprav v zvezi s socialnimi ukrepi) smo že razpravljali (Mrgole, 1996c), vendar je v Sloveniji ta problematika šele $\mathrm{v}$ začetni fazi teoretskega razmišljanja, pa tudi praktičnega delovanja. (O družbeni senzibilnosti, ki bi pripomogla $\mathrm{k}$ usklajeni medresorni podpori na državni ravni, pa ob parlamentarni dinamiki sprejemanja državnega proračuna za leto 1997 nima smisla tratiti intelektualne energije).

Izstopanje mladih iz šolskega sistema ima s sociološkim razmišljanjem o samomoru, ka- 
Govoriti o mladih v izobraževanju odraslih je bilo tudi pred nekaj leti heretično, kot je še vedno, kadar kdo v šolsken sistemu razmislia o enakopravnosti in avtonomnosti sistema izobraževanja odraslh. Danes so nladi pedagoški oziroma andragoski objekt obeh sistemov. Paradoks je seveda dvosmeren: če redni śolski sistem izobraževanju odraslih odstopi zahtevane pristojnosti, s tem implícitno prizna lasten neuspeh, sistem izobraževanja odraslih pa se lahko po drugi strani konstitura le v olviru šolskega sistema in ima nujno opraviti z liudmi, ki iz tega sistema (tako ali drugače) izhajajo. Pri tem pa polożaj mladih v sistemu izobraževanja in njihove realne izobraževalne možnosti pomenijo akutni simptom opisane sistemske paradoksnosti. Ker se vsi, ki jh prisilno tlacijo/mo v śole, niso sposobni solati, je še bolj res, da tudi śolski sistem - zlasti sistem nadaljevalnega šlanja po osnovni šoli - ni primeren za vse, ki si priborijo njegov vstopni vizum. $Z$ nasprotne strani se zdï nekako samomorilsko, ko ugotavJamo, da mladi množično izstopajo iz nadaljevalnega solanja, ki jim zagotavlja certiffkat prexivetja, tisti certiflkat, ki odpira vrata $v$ svet zaposlovanja in odraslh. S stalisča fenomena podal Śsane mladosti, po katerem bi vsi radi čm dlje ostali mladi (Gilis, 1993), se tudi podalǰsuje cas, ki ga mladì danes želijo preživeti kot izkliučeni s podrocja dela. Tudi s tega vidika se zdi šolanje še najboljśsa strateśko-ekonomična prilożnost.

kor ga je razvijal Durkheim pred natančno sto leti (Durkheim, 1992), še eno skupno metodološko značilnost: za vsako zgodbo (tokrat zgodbo o neuspehu) je namreč značilna individualna naključnost, ki je sicer sama na sebi dramatična in zanimiva, vendar tega, da vsako leto ostane brez možnosti za nadaljevanje šolanja vsaj ena tretjina generacije, ne moremo pojasnjevati brez upoštevanja družbenih dejavnikov, ki pa niso povsem nenaključni in nepredvidljivi.

Za izločene ostajajo izobraževalni programi za odrasle nadomestna oblika in dejstvo je, da se v posamezne andragoške izobraževalne programe, od osnovne šole za odrasle, programov UŽU, CMO, USO do informativnih in motivacijskih delavnic, ki jih organizira Republiški zavod za zaposlovanje, čedalje pogosteje vpisujejo udeleženci, ki jih kljub precejšnji dobrohotnosti ne moremo označiti kot odrasle. Andragoška terminologija jih je doslej označevala kot mlajše odrasle, to pa po resnejšem premisleku in praktičnih izkušnjah pri delu z ljudmi, ki so stari od 15 do 25 let, anticipira določene komunikacijske zagate, še zlasti pri morebitni interdisciplinarni komunikaciji. Zato smo namesto sedanje kategorije »mlajši odrasli « predlagali kategorijo »mladi v izobraževanju odraslih« (Mrgole, 1997).

Pri tem bo kdo ugovarjal, da po nepotrebnem obremenjujemo komaj vpeljano andragoško opredelitev ciljne skupine mlajših odraslih. Prednost takšne klasifikacije vidimo v luči kritike stališč do mladine, ki so jih oblikovale pozitivistične težnje $\mathrm{v}$ humanističnih disciplinah $\mathrm{v}$ preteklosti. Mladost je ideološka kategorija, ki jo težko enoznačno in "objektivno" opredelimo. Zato bomo $\mathrm{v}$ pričujočem prispevku skušali prikazati družbene razsežnosti problematike, ki zajema mlade kot udeležence $\mathrm{v}$ izobraževalnih programih, in pokazati, da "narava "problematike nujno presega ozko domeno pedagoške ali andragoške tehnologije ter je prej sociološki, antropološki in psihološki teoretski raziskovalni problem $\mathrm{v}$ multidisciplinarni perspektivi.

\section{ŠOLSKI OSIP IN PARADOKSI STATISTIČNIH PODATKOV}

Pri animaciji za drugo izvedbo eksperimentalnega projekta CMO (Center za mlajše odrasle, namenjen mladim osipnikom) smo izvedli kar nekaj informativnih pogovorov s svetovalnimi delavci na terenu, ki poznajo resnično dinamiko šolskega osipa. Njihova ocena o mladini, ki zapusti šolanje, daje občutek katastrofalnega stanja. Ali lahko parcialno mnenje poznavalcev na terenu prikažemo tudi številčno?

Statistična podatkovna zaloga - viri na MŠŠ, podatki RZZ, Statistične informacije (vzgoja in izobraževanje - SURS), Statistični podatki po občinah (Zavod RS za statistiko), Rezultati raziskovanj (Zavod RS za statistiko), Demografska statistika (SURS) - je na prvi pogled 
bogat podatkovni instrumentarij, vendar je za naše potrebe premalo distinktiven, saj večinoma zabriše pretanjeno dinamiko posameznih kategorij, ki nas zanimajo, in postreže $\mathrm{z}$ zelo ohlapnim povprečjem. Starostne kategorije, po katerih je izvedena splošna demografska statistika, se vedno ne ujemajo s predvidenimi položaji. Starostne opredelitve od 15 do 19 let (ki jih upošteva statistična obdelava) se uvrščajo na dve ravnini prehoda: najprej iz osnovne šole $\mathrm{v}$ srednje šolanje, nato pa iz srednjega šolanja $\mathrm{v}$ visoko. Tako sta s to kategorijo zajeta dva različna prekrivajoča se statusa, ki hkrati zameglita dinamiko prehajanja (starostna meja 15 let ne pomeni nujno tudi končanega osnovnega šolanja, prav tako dopolnjeno 19. leto ne pomeni končanega srednjega šolanja). Natančno število se nam s tem izmika in zato lahko le sklepamo, da je osip v osnovnih šolah v zadnjih petih letih (1991-1996) med šestimi in sedmimi odstotki (Statistične informacije), da šolanje po osnovni šoli nadaljuje 87 odstotkov populacije (podatki o vpisu v 1 . letnik zajemajo vse šole, vključujejo pa tudi ponavljalce). Iz Bele knjige (1995: 232) lahko povzamemo, da znaša število ponavljalcev $\mathrm{v}$ prvih letnikih dve-, tri- in štiriletnih srednih šol zadnja leta v povprečju 8 odstotkov. Zato moramo te podatke brati križno in s precejšnjo raziskovalno intuicijo.

Ker je mladina že od antike estetski objekt občudovanja, bomo za začetno estetsko "ugodje" v nadaljevanju predstavili nekaj ponazoritev, ki jih je navdahnilo lansko državno poročilo o mladini $\mathrm{v}$ Sloveniji (Ule, (ur.), 1996a), v primerjavi z nekaterimi mednarodnimi komparativnimi navezavami ter podatki, ki smo jih zbrali sami (Mrgole, 1996e).

\begin{tabular}{|c|c|c|}
\hline \multicolumn{3}{|c|}{ Tabela 1: Starostne skupine v letu 1992} \\
\hline 15-19 let & 144.900 & 7,4\% celotne populacije \\
\hline $20-24$ let & 143.629 & $7,3 \%$ celohne populacie \\
\hline
\end{tabular}

Demografske študije iz leta 1995 kažejo, da se delež populacije do leta 2020 ne bo bistveno spreminjal, kar pomeni, da bo četrtina prebivalcev Slovenije všteta v kategorijo mladih med 15. in 29. letom. Iz osnovne demografske matrice lahko tako izpeljemo nekaj značilnih strukturnih kategorij, ki bodo pomenile oceno morebitnih udeležencev v sistemu izobraževanja odraslih neposredno po izstopu iz rednega sistema šolanja.

Tabela 2: Stopnja delovne aktivnosti po starostnih
skupinah za lelo 1994
\begin{tabular}{|l|l|}
\hline 15-19 let & $7,5 \%$ \\
\hline $20-24$ let & $56,5 \%$ \\
\hline $25-29$ let & $80,9 \%$ \\
\hline
\end{tabular}

Vir: Geržina v: Ule, 1996a: 122.

$\mathrm{Na}$ naslednji tabeli je nekoliko natančneje prikazano prehajanje mladih iz šolskega sistema na trg delovne sile. Prikazuje dinamiko

$\mathrm{Za} 7,5$ odstotka populacije mladih med 15 . in 19. letom starosti, ki je opredeljena kot delovno aktivna, jh je (po Geržina, ibid.):

- 43 odstotkor zaposlenih za doloćen čas, kar pomeni negotovost med brezposelnostjo in delom za nedoločen čas;

- 9 odstotkov zaposlenih pa išče drugo zaposlitev.

priliva mladih, ki iz šol prehajajo $\mathrm{v}$ kategorijo aktivnega prebivalstva, v kateri jih ima več kot polovica končano poklicno ali srednje izobraževanje (skupaj $\mathrm{z}$ osipom študentov), dobra četrtina pa komaj končano osnovno šolo ali pa niti te ne (Kraigher, 1994: 19-20).

\begin{tabular}{|c|c|c|c|}
\hline \multicolumn{4}{|c|}{$\begin{array}{l}\text { Tabela 3. Stevilo priliva iz šolskega sistema } \\
\text { v let'h 1988-1993 }\end{array}$} \\
\hline & $\begin{array}{l}\text { priliv } \\
\text { iz OS }\end{array}$ & $\begin{array}{l}\text { priliv } \\
\text { poos }\end{array}$ & $\begin{array}{l}\text { priliv } \\
\text { posśs }\end{array}$ \\
\hline 1988 & 2.576 & 3.730 & 14307 \\
\hline 1989 & 3.567 & 4.119 & 12.810 \\
\hline 1990 & 2756 & 1.538 & 13.860 \\
\hline 1991 & 3.055 & 4.379 & 13.281 \\
\hline 1992 & 783 & 4.018 & 14.054 \\
\hline 1993 & 2.849 & 4.100 & 13.816 \\
\hline povpreče ' $88^{-1}-93$ & 2.600 & 3.650 & 13.680 \\
\hline \multicolumn{4}{|c|}{ (povzeto po: Kraigher, 1994:20) } \\
\hline
\end{tabular}

Tabeli sta starostno in vsebinsko premalo distinktivni, da bi bili lahko podatki analitično uporabni. Kljub temu lahko na tabeli 3 vidimo, da je število mladih, ki po posameznih izobraževalnih stopnjah prehajajo na trg dela, dokaj konstantno, ne glede na različno dolžino trajanja izobraževalnih programov. Pri tem je tudi število vpisanih dijakov v srednje šole - kljub pestri dinamiki ponavljanja, prepisovanja, izstopov, generacijskih odmikov - po letu 1989 dokaj konstantno in vedno večje kot 30.000 (Bela knjiga, 1995: 231, 232). Skratka, če se strinjamo, da nam kon- 
stantni števili vpisanih in tistih, ki iz srednjih šol prehajajo na trg delovne sile, pomenita strukturni kategoriji, preprost račun pokaže (prav tako strukturni) primanjkljaj od 16.000 do 17.000 posameznikov.

Največji delež mladih prihaja na trg delovne sile po končanem srednjem šolanju. Natančnejši podatki o vključenosti mladih v izobraževanje so na naslednji tabeli:

\begin{tabular}{|c|c|c|}
\hline \multicolumn{3}{|c|}{$\begin{array}{l}\text { Tabela 4: Vključenost mladih v izobraževanje v } \\
\text { lełu } 1994 / 95\end{array}$} \\
\hline $15-19$ let & $78 \%$ & 117.631 \\
\hline $20-24$ lef & $21,3 \%$ & 30.390 \\
\hline $25-29$ let & $4,6 \%$ & 6.875 \\
\hline \multicolumn{3}{|c|}{ Vir: Mencin, Ceplak v: Ule 1996a, 76.} \\
\hline
\end{tabular}

V zvezi z demografskim mozaikom mladine izpred treh let, ki ga skušamo sestaviti, je čas za prvi poskus generalizacije. Ker demografske analize napovedujejo prvo večje zmanjšanje generacije za leto 1997, lahko oceno za leto 1994 uporabljamo kot dokaj zanesljivo konstanto večletne dinamike. Prav tako lahko sklepamo, da je število osipnikov dokaj konstantno. Naslednja tabela nazorno prikazuje strukturno razsežnost problema, ki se na prvi pogled sicer zdi individualno pogojen in naključen, $v$ daljšem časovnem obdobju pa se pokaže dinamika dolgega trajanja kot sistemska konstanta.

\begin{tabular}{|c|c|c|c|c|}
\hline \multicolumn{5}{|c|}{ Tabela 5: Mladi med delom in šolo v lelu 1994} \\
\hline \multirow[t]{2}{*}{ starost } & velkest staroshe & delono & Nuvieni & nepoiasnifeno \\
\hline & skupine & dkivini & vizobrozivenge & \\
\hline \multirow[t]{2}{*}{$15-19$} & 144.900 & 10.867 & 17.631 & 16.402 \\
\hline & 1100\%: & 17,5\%) & 178\%: & $\mid 4,5 \%:$ \\
\hline \multirow[t]{2}{*}{$20-24$} & 143.629 & 81.150 & 30,390 & 32089 \\
\hline & 1100\%) & (56,5\%) & $12,3 \%$ & $122,2 \%$ \\
\hline
\end{tabular}

Po anketi o delovni sili za leto 1994 je brezposelnost mladih $\mathrm{v}$ Sloveniji in $\mathrm{v}$ primerjavi $\mathrm{z}$ drugimi državami EU občutno večja prav pri mladih med 15. in 19. letom. Pri tem naj opozorimo, da statistike zavodov za zaposlovanje zelo rade združujejo mlade od 15 . do 24 . leta v enotno skupino, kar v povprečju nekoliko prikrije izrazite slovenske odmike. Podatki RZZ o brezposelnih navajajo dve kategoriji, ki pa se prekrivata in sta za nas premalo razlikovalni, in sicer iskalce prve zaposlitve in brezposelne do 26 let, ne navajajo pa kategorije registriranih brezposelnih med 15. in 19 . letom.

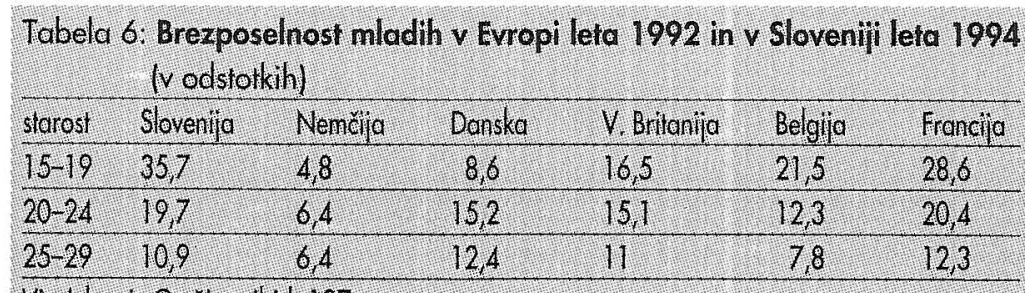

Vir: lzbor iz Geržna, bid: 127.

Obravnavane podatke lahko strnemo v poskus odgovora na iskanih dobrih 16.000 ljudi, starih od 15 do 19 let, ki niso zajeti med aktivnimi in šolajočimi se vrstniki (to sta približno dve tretjini šolske generacije), ter tudi 32.000 mladih, ki jih čaka enaka usoda med 20. in 24. letom. Ali so omenjene številke realne?

Zadnja analiza uspešnosti šolske generacije je bila opravljena pred 15 leti. V generaciji, ki se je v letih 1982/83 in 1984/85 vpisala v srednje izobraževanje, je bil 20-odstoten osip (Zavod RS za zaposlovanje, september 1990, delovno gradivo). Prvega letnika ni končalo 16 odstotkov dijakov in dijakinj (križno branje s podatkom o ponavljalcih v 1 . letniku - Bela knjiga, 1995: 232 - pri predpostavki, da gre za razvoj, pokaže, da 8 odstotkov vpisane populacije ne nadaljuje šolanja že takoj po prvem letniku).

Popis '91 (Zavod RS za statistiko, november 1992) pa navaja, da je bilo v izobraževanje vključene 73,45 odstotka populacije med 15 . in 19. letom. Več kot 18.000 mladih brezposelnih med 15. in 25. letom v tem času ni imelo osnovnega poklica (niso dokončali poklicnega izobraževanja ali osnovne šole).

Na podlagi podatkov za izobraževanje lahko za leto 1995 ugotovimo, da je kljub povečanju izobrazbene ravni prebivalstva $\mathrm{v}$ šolah precejšen osip: na osnovni šoli ob prehodu $\mathrm{v}$ srednje šolanje 7-12 odstotkov, $v$ srednjih šolah pa vsako leto izpade kar četrtina šolajoče se generacije (vir: Urad Republike Slovenije za mladino). Po grobih ocenah bi lahko sklepali, da 20 odstotkov populacije po osnovni šoli ne nadaljuje šolanja.

Iz Bele knjige (1995: 231) smo že navedli število vpisanih $\mathrm{v}$ prvi letnik srednjega šolanja. Dinamika vpisa $\mathrm{v}$ zadnjih letih kaže porast: prvega lahko vidimo med letoma 1985 (26.504) in 1989 (31.023), naslednjega v letih 1991-1993, ko se je število povečalo na skoraj 33.000. Kako naj ta porast interpreti- 


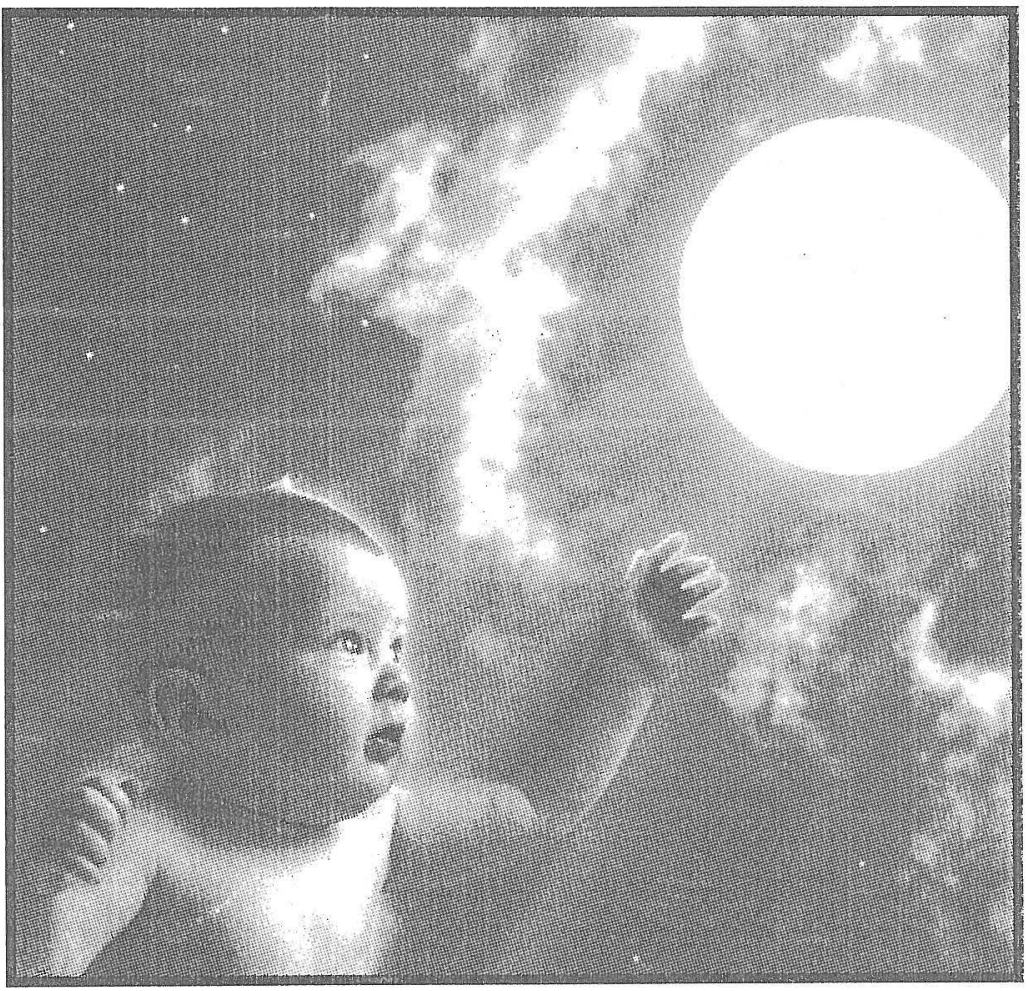

ramo v zvezi z zmanjšanim številom generacije, ki končuje osnovno šolo, in dokaj konstantnim deležem vpisa osnovnošolcev $\mathrm{v}$ 1. letnik nadaljevalnega šolanja (približno 80 odstotkov)?

V letu 1995 je bilo 10 odstotkov mladih med 15. in 19. letom delovno aktivnih, med 20. in 25. letom dve tretjini, med 25. in 29. letom pa 90 odstotkov. Delež registriranih brezposelnih oseb, starih do 26 let, je ob koncu leta 1994 znašal povprečno 33 odstotkov, med njimi pa jih je bilo največ $\mathrm{z}$ nedokončano osnovno šolo (34 odstotkov), s končano poklicno šolo (26 odstotkov) in končano srednjo štiriletno šolo (29 odstotkov) - vir: Urad Republike Slovenije za mladino.

Ti podatki so na splošno pomanjkljivi, nezadostno razločevalni, rezultati niso vedno logični, združevanje rezultatov nas vodi do kontradikcij, prihaja do izgube ali presežka populacije ipd. Sistem srednjega šolanja je zajet kot celota, posebej bi bilo treba obravnavati poklicne šole, posebej tehnične in posebej gimnazije (vpis, dinamika osipa, prepisovanje, dokončanje). Bolj kot prikaz v odstotkih (ki je vedno nevaren zaradi zavajajočih deležev) nas zanimajo absolutne številke: koliko mladih je dejansko brezposelnih. Različni avtorji navajajo dokaj različne podatke. Opredeljena raziskovalna vprašanja zahtevajo temeljitejšo lon- gitudinalno študijo statističnih podatkov (za obdobje 1990-1996), predvsem na podlagi komparativnega križanja posameznih podatkov in križnega izračunavanja različnih statističnih virov. Čeprav podatki ne bodo aktualni, lahko od takšne raziskave pričakujemo "zgodovinsko lekcijo " o obsegu strukturno pogojenega osipa. Poleg tega je treba izdelati smiselne profile posameznih primerov strategije šolanja, ki bi jih statistično spremljali po razvojni logiki, na primer dokončanje osnovne šole, prehod na poklicni program (vpis), število diplomantov (po treh letih), kar bi nam omogočilo $\mathrm{v}$ časovni perspektivi določitev deleža uspešno končanega poklicnega izobraževanja ter $\mathrm{v}$ primerjavi $z$ deležem vpisanih (prav tako $\mathrm{v}$ časovni perspektivi) oceno osipa $v$ poklicnih šolah kot predikcijsko variablo. Poleg tega je treba generalizirane statistične podatke o uspehu računati na začetku in koncu šolskega leta (september-junij) in naprej, spremljati dinamiko prepisovanja $\mathrm{v}$ različne izobraževalne programe.

Sedanji način zbiranja podatkov nam tega ne omogoča, zato naj navedemo nekaj križnih primerjav in paradoksov, pred katerimi se znajdemo ob poskusu interpretacije:

- Število populacije med 15. in 19. letom je bilo v letu 1994 145.000. Septembra 1994 je končalo osnovno šolo 26.611 posameznikov. V 1. letnik srednjih šol (skupaj s ponavljalci) se jih je vpisalo 32.862 . Ce jih 80 odstotkov nadaljuje srednje šolanje (iz Nacionalnega programa Urada za mladino, 1996, podatek o vključenosti populacije med 15. in 19. letom v šolanje spet ni dovolj distinktiven: ali so zajeti tudi osnovnošolci in študenti), se jih je v 1. letnik vpisalo približno 21.300. Razlika v primerjavi z vsemi vpisanimi $\mathrm{v} 1$. letnik leta 1994 znaša 11.551 (ena tretjina). Če upoštevamo, da je ponavljalcev v 1 . letniku okrog 8 odstotkov, je to le približno 2.500 dijakov manj. Torej jih še vedno ostane 9.000 nepojasnjenih (10 odstotkov vseh šolajočih je v starosti med 15. in 19. letom). Ali gre za tiste, ki se prepisujejo, ki se sicer vpišejo, pa ne končajo ali pa sploh ne obiskujejo pouka, ali gre za delež tistih, ki se preprosto nehajo šolati? Srečo Zakrajšek (1995: 317) trdi, da se bomo morali brez večjih moralnih zadreg sprijazniti z dejstvom, "da pač 10 ali 15 odstotkov otrok ni za šolo«. Vendar so tudi druge interpretativne možnosti: čedalje več mla- 
dih ob anticipaciji neuspeha samih od sebe preneha šolanje, izstopijo iz šolskega programa pred koncem šolskega leta, ker tako formalno niso označeni kot ponavljalci. Po dveh neuspešnih ponavljanjih šolski sistem namreč mladim ne dovoljuje nadaljevanja šolanja in jim s tem onemogoča prehajanje med različnimi izobraževalnimi programi.

- Če upoštevamo podatek, da je ena tretjina vsake generacije brez osnovnega šolanja ali osnovnega poklica, pridemo pri številu 25.000 prav tako do števila približno 8.000 .

- Podatki za leto 1994 kažejo razmerje vpisanih v srednje šole: 58 odstotkov (gimnazije in tehniške šole) proti 42 odstotkom (dveletne in triletne poklicne šole) - Bela knjiga, 1995: 231, slika 14.

Vendar nas bolj kot sami podatki o številu šolskih osipnikov zanimajo podatki, ki bi omogočili kvalitativno analizo in longitudinalno spremljanje dinamike izstopanja iz šolskega sistema. Pri tem se nam postavljajo nekatera vprašanja, ki bi zahtevala poseben raziskovalni pristop $\mathrm{k}$ razpoložljivim statističnim podatkom in nam pomagala ugotoviti:

- Koliko je omejitev vpisa v posamezne programe srednjega šolanja merilo zaposlitvene politike (število omejenih vpisnih mest), kakšna so merila po področjih in kakšna je dejanska distribucija $\mathrm{v}$ prvi letnik nadaljevalnega šolanja, kolikšno je število zavrnjenih, ponovno vpisanih, prepisanih $\mathrm{v} 1$. letnike poklicnih, srednjih šol in gimnazij proti številu uspešno/»zadovoljno« vpisanih? Kolikšen je delež populacije, ki ne nadaljuje šolanja po osnovni šoli? Kolikšen je delež s končano osnovno šolo proti deležu z izpolnjeno šolsko obveznostjo in nedokončano osnovno šolo?

- Kakšne oblike poklicnega odločanja uporabljajo kandidati na različnih izobraževalnih smereh oziroma stopnjah (gimnazije, tehniške in poklicne šole)?

- Koliko se kandidati vpisujejo na podlagi individualnih dispozicij in koliko zaradi zunanjih omejitev (predpostavka o primerjavi nemotiviranosti za šolanje zaradi neuspešnih oziroma "nesrečnih " vpisov iz stiske $\mathrm{z}$ dinamiko in deležem dejanskega šolskega neuspeha)? Katere smeri in kateri programi producirajo največ osipnikov?

- Kako in v kolikšnem obsegu poteka dinamika migracij iz zahtevnejših $v$ manj zahtevne programe (po področjih)?
- Koliko populacije izpade iz osnovnošolskega sistema, koliko je nadaljuje šolanje? Koliko izpadlih se zaposli po osnovni šoli, koliko pa izpadlih iz srednjega šolanja? Kakšno zaposlitev izbirajo?

- Ali lahko na podlagi križnega branja podatkov o osipu ugotovimo, koliko jih dejansko ostane brez poklica, brez zaposlitve in možnosti za nadaljevanje izobraževanja?

- Velikost generacije (vpis v osnovno šolo, dokončanje, vpis $\mathrm{v}$ srednjo šolo, izpad, dokončanje) in primerjava s statističnim povprečjem (kakšna je dinamika absolutnih števil).

Statistični podatki so argument $\mathrm{z}$ omejeno vrednostjo, saj moramo za potrebe pragmatičnega načrtovanja mladinskih izobraževalnih programov nujno preiti $k$ opredelitvi kvalitativnih kategorij, ki nas seznanijo $\mathrm{z}$ nekaterimi temeljnimi značilnostmi mladih in so izhodiščni dejavniki pri razmišljanju o pripravi ustreznih izobraževalnih programov.

\section{IZHODIŠČA ZA NAČRTOVANJE MLADINSKIH IZOBRAŽEVALNIH PROGRAMOV}

Pri načrtovanju izobraževalnih programov načrtovalci vedno izhajajo iz premisleka o ciljni skupini. V nadaljevanju bi radi najprej opozorili na ideološke postavke in njihove konsekvence, ki se jim pri načrtovanju nikakor ne moremo izogniti. Izobraževalni programi kot svojo izhodiščno argumentacijo postavljajo določevanje izobraževalnih potreb, ki temelji na analizi ciljne skupine. Pri sociološkem konceptu družbenih potreb se zdi Parsonsova sociologija, ki človekove potrebe poenostavljeno zvede na raven pedagoško prevedljivih tipov, najbolj funkcionalno uporabna in aplikativna. Pri tem se posameznikove potrebe, kakor jih je opredelil Maslow, in ki jih po njem tako radi določajo teoretiki načrtovanja izobraževalnih programov, zvedejo na poenostavljen obrazec učnega pogojevanja. Tako sicer res pridobimo pri pedagoškem optimizmu, vendar so to prednosti, ki so zelo kratkoročne. $\mathrm{Z}$ aplikacijo pozitivističnih in funkcionalističnih opredelitev v praksi izobraževanja zmeraj nastajajo presežki in miselni paradoksi, na katere bi radi opozorili v nadaljevanju. Paradoksna je 
že sama določitev izobraževalnih potreb, na kar je nazadnje opozoril Davidson (1995).

Temeljno vprašanje je, kako načrtovalci izobraževalnih programov družbene potrebe spremenijo v izobraževalne. $S$ tem so aktivnosti, ki iz tega procesa izhajajo, vodene s potrebami oziroma bi lahko izobraževanje odraslih v temelju opredelili kot iz potreb izhajajočo aktivnost (needs-making activity). Če definiramo izobraževalno potrebo po modelu diskrepance, kakor jo je opredelila Witkinova (1984, cit. po: Davidson, 1995), kot razliko med željo posameznika in realnostjo (na ravni razmer ali stanja stvari), je omenjeni precep pri mladostnikih zelo težko enoznačno artikulirati in prevesti na raven izobraževanja. Model diskrepance potreb lahko uporabimo pri načrtovanju programov, pri katerem sta dokaj jasni dve ravni (na primer zahteva okolja oziroma dela po znanju tujega jezika in želja posameznika, da se nauči tujega jezika, ki ga potrebuje za nemoteno delovanje $\mathrm{v}$ svojem okolju oziroma pri delu). Pri izobraževanju mladih (splošnem) pa so zahteve okolja oziroma realnosti, iz katere izhajajo zahtevane spretnosti, postavljene $\mathrm{v}$ negotovo in dinamično spreminjajočo se prihodnost (razvoja tehnike, tehnologije dela, spretnosti, ki jih bodo mladi potrebovali, stanja na trgu delovne sile, zaposlitvenih možnosti ... ni mogoče jasno predvideti). Torej se želje mladih ne morejo jasno arti-

O težavah pri identifikaciji aktualnih izobraževalnih potreb gre na eni strani za raven posameznika, na drugi pa za raven družbenih pogojev, ureditve, strukture, tehnologije in financ. Navedena ugotovitev pomeni v praksi pripravo izobraževalnih programov, $\mathrm{ki}$ zelo hitro upośtevajo spremembe na trgu dela in z razvojem tehnologije pogojene spremembe delovnih zahtev. Tako pri dolečanju sizobraževalnih potreb « nujno zapolnimo nezvedlijo vrzel med individualnim in družbenim $\mathrm{v}$ korist slednjega, kar $\mathrm{v}$ skrajni konsekvenci pomeni, da je določitev izobraževalnih potreb vedno že normativno početje; saj gre za vplivanje enega človeka (ali skupine - to je načrtovalcev izobraževalnega programa) na vedenje drugega oziroma drugih.

kulirati na ravni do stanja oziroma zahtev hipotetične prihodnje realnosti, še zlasti ne izobraževalne želje. Tako je opredelitev izobraževalnih potreb mladih poseg načrtovalcev izobraževalnih programov, ki pravzaprav ne morejo upoštevati realnih potreb ciljne skupine. Sklep te izpeljave je, da na ravni ča- sovne diahronije o izobraževalnih potrebah ne moremo govoriti. Model Witkinove lahko tako rešuje le aktualna neskladja na sinhroni ravni, kar nas v radikalizirani različici privede na sam rob argumenta vseživljenjskega učenja.

Na nov kartel, ki v izobraževanju določa potrebe drugim, je prav tako že leta 1978 v delu »Toward a History of Needs « opozoril sloveči kritik šolskega polja Ivan Illich. Davidson in tudi nekateri drugi avtorji (Collins, Jarvis, Griffin) ugotavljajo, da je določanje izobraževalnih potreb ena izmed sestavin šole kot političnega in ideološkega aparata države, nikakor pa ne tehnično vprašanje kurikularnega načrtovanja. Na tej podlagi lahko še naprej razmišljamo, da načrtovalci $\mathrm{z}$ opredelitvijo pojma "izobraževalne potrebe « zapadejo nereflektirani pedagoški imaginaciji in $\mathrm{z}$ določitvijo izobraževalnih potreb reproducirajo družbene ideološke razmere, $s$ tem pa tudi razredno delitev, strukturno neenakost in vse pritikline vsakdanjih težav sodobnega postindustrijskega življenja.

Pozitivistična določitev individualnih izobraževalnih potreb omenjeno logiko prevede na raven pedagoške recepcije in $s$ tem zagotovi praktično izvedbo. Menimo, da rešitev ni $\mathrm{v}$ odločitvi za individualno ali politično ideološko perspektivo, temveč $\mathrm{v}$ refleksivnem zavedanju morebitnih učinkov pedagoške dejavnosti. Skratka, v analizi samoumevnih predpostavk, ki vodijo načrtovalce pri določanju izhodiščnih izobraževalnih predpostavk. Zato se ne odrekamo perspektivi določanja ciljne skupine, ki poleg individualnih vključuje tudi širše družbene (kritičnosociološke in antropološke) perspektive ter $\mathrm{s}$ tem omogoča bolj reflektirano opredelitev ciljne skupine. Prednost omenjenega metodičnega pristopa je $\mathrm{v}$ tem, da se izognemo nevarnosti psihologiziranja in iracionalnega pedagoškega romantiziranja. Brez upoštevanja družbenih argumentov smo namreč $v$ nenehni nevarnosti, da se nam $\mathrm{v}$ premislek vplete le vidik individualnih perspektiv, kar vodi tudi k nevarnosti poenostavljanja in h konceptom, ki patologizirajo in stigmatizirajo (učne težave, osebnostne motnje, vedenjske motnje ...). Namesto vprašanja, kaj je $\mathrm{v}$ individualni psihi tisto, kar pojasnjuje določeno ravnanje oziroma odločitev posameznika (izstop iz šolskega sistema, samomor), je za načrtovalce izobraževalnih 
programov učinkovitejše, če se vprašajo, kaj $\mathrm{v}$ resnici spodbuja posameznika kot avtonomnega subjekta in katere možnosti mu lahko ponudimo kot alternative. Ali so te možnosti določene $\mathrm{z}$ razumevanjem družbene pogojenosti in jih lahko omogoči izobraževanje? Drugače rečeno, ali se vzrok za šolsko osipništvo morda skriva $v$ razumevanju dinamike poklicnega odločanja, ki se znajde $\mathrm{v}$ zagati med individualno željo in (ne)možnostmi spreminjajoče se realnosti?

Raziskovalci mladinske brezposelnosti $\mathrm{v}$ 70. in 80 . letih so ustvarili določene vrste tipologije, ki temeliijo na statistično določenih skupnih znaćilnostih obravnavanja dramatičnega povečanja mladinske brezposelnosti $\mathrm{v}$ zahodnoevropskih industrijskih državah. Rezultate (umetno konstruiranih) statističnih tipov sodobne raziskave kritizirajo kot preveč rigidne ter predlagajo oživitev raziskav $\mathrm{z}$ vidika kritične teori$\mathrm{je}$ in kulturne razredne analize. To bi $\mathrm{v}$ perspektivi onogocilo razumevanje razmerij moči družbenih dejavnikov, ki imajo ključno vlogo pri identitetni formaciji mladih (Pye et all., 1996: 133,4). Predvsem se v poindustrijski družbi pojavlja množica kontradiktornih diskurzov, ki vstopajo v preplet formiranja poklicne identitete mladih.

Prvi argument, ki se implicitno prikrade v pojasnjevanje individualnega ravnanja, je $\mathrm{v} \mathrm{kr-}$ ščanski kulturi povezan $s$ samoumevnostjo vpeljave pojma individualne krivde oziroma rabe pojma individualne odgovornosti v protestantski kulturi. Menimo, da še zlasti pri delu z mladimi, ki šele začenjajo zaznavati družbeno realnost in jo po svoje tudi kritično reflektirajo, raba koncepta individualne odgovornosti (krivde) zgreši možnost oblikovanja temeljnega komunikacijskega prostora. Učinkovitejše kot vidik individualne odgovornosti se pokaže razmišljanje o strukturnih oziroma družbenih razmerah, ki posameznikom šele omogočajo razmere za njihovo delovanje. Omenili smo že iracionalnost odločitve izstopa iz šolskega sistema, ki z antropološkega vidika pomeni pomanjkanje življenjske strategije. Vendar je to po drugi strani zavestna odločitev, ki temelji na precejšnji individualni angažiranosti. Kako naj jo torej interpretiramo? Razmišljanje o individualnih zgod- bah nas bo zavedlo v slepo ulico psiholoških zgodb in ne bo pojasnilo množičnosti. Pomembnejši kot moralistične ideje o individualni odgovornosti so družbeni dejavniki kot danost, ki jo moramo poznati.

Iz sodobnih raziskav o generaciji mladih, ki doživlja prehod $\mathrm{k}$ odraslosti $\mathrm{v}$ evropski poindustrijski družbi, izhaja sprememba mentalitetne danosti, ki ustvarja družbeni odnos do mladosti. Novo mentalitetno podobo mladih sestavljajo kumulativni učinki visoke stopnje brezposelnosti, slabših zakonskih možnosti za šolske osipnike, odtegnitev državne finančne podpore in medijske reprezentacije, ki ustvarja paniko o brezposelni mladini.

Tudi na Slovenskem se v izobraževalnih programih, namenjenih odraslim, vsako leto bolj množično pojavljajo mladi, ki jih pogovorno opisujemo kot populacijo brez poklica, zaposlitvenih izkušenj in so zato označeni kot družbena kategorija najtežje zaposljivih. $\mathrm{Z}$ besedami funkcionalistične sociologije lahko govorimo o njihovi statusni deprivaciji, v sociološko kulturnem pomenu pa njihov problem opredelimo kot nenavzočnost družbeno pričakovanih statusov: izpadli so iz sistema, ki podeljuje status dijaka, in ni jim uspelo vstopiti v družbeno polje, ki zagotavlja status delavca, na kar se navezujejo širši družbenonormativni pritiski (Mrgole, 1997). Mladi, ki sestavljajo opisano ciljno skupino, so v literaturi primarno opredeljeni kot marginalizirana mladina (Ketter et all., 1987: 32; Petersen et all., 1994; Ule, Miheljak, 1995). Družbena marginalizacija je le konsekvenca izstopa iz sistema izobraževanja in posledica statusne nevključenosti (dijaka oziroma zaposlenega) (Mrgole, 1997: 13-19). Med načrtovalci izobraževalnih programov se za omenjeno kategorijo uporablja tudi izraz

\section{Prevalitev krivde za brezposelnost mladih na njih same je nevzdržna.}

"posebne skupine s posebnimi zahtevami «, (Kallen, Denis, 1996), za katere je treba še posebej pazljivo pripraviti izobraževalne programe. Vendar bolj določenih teoretskih artikulacij, ki bi opredelile izhodiščne elemente pri načrtovanju kurikuluma za marginalizirano mladino, $v$ literaturi doslej še nismo zasledili.

Iz zagate med opisano metodično usmeritvijo in pomanjkanjem ustreznih praktičnih rešitev si bomo skušali pomagati po svoje. $V$ nadalje- 


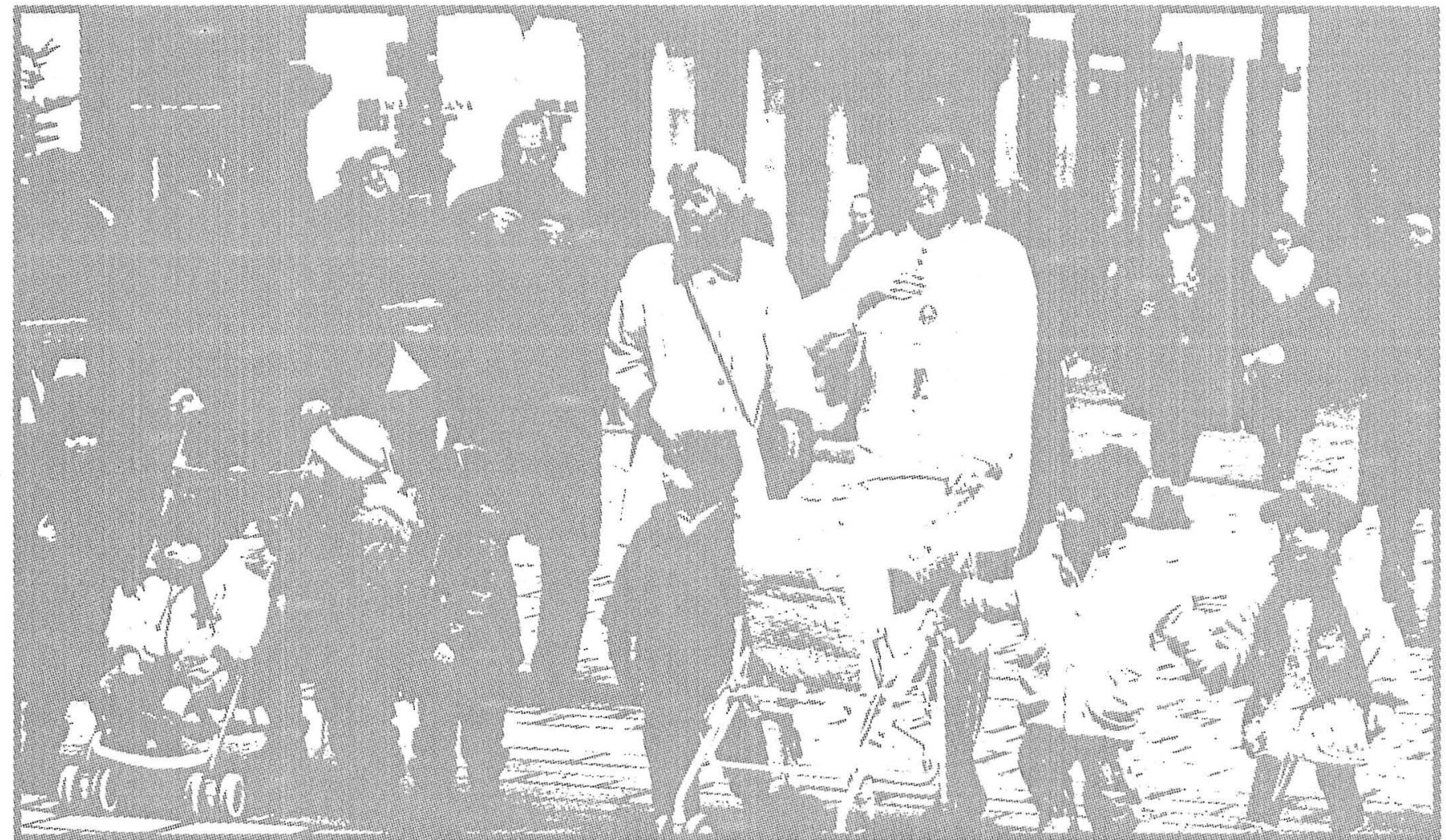

vanju bomo povezali strukturne kategorije ciljne populacije in orisali izhodiščne elemente pri načrtovanju alternativnih izobraževalnih programov za mlade. Pri tem bomo združili izkušnje raziskovalnega dela in programa Projektno učenje za mlade (PUM) ter rezultate neposrednega spremljanja oziroma evalvacije eksperimentalnega projekta CMO (Center za mlajše odrasle), ki smo jih opravili v zadnjem letu na Andragoškem centru Slovenije. Iz dinamike načrtovanja poteka izobraževalnega programa želimo poudariti nekaj značilnih kategorij in pričakovanih specifičnih lastnosti mladih, ki so se v praksi načrtovanja pokazale kot uporabne. Pričakovane lastnosti ciljne skupine smo sicer razdelili $\mathrm{v}$ dve skupini, vendar omenjene delitve pri delu $\mathrm{z}$ mladimi ne moremo obravnavati povsem ločeno:

1. Objektivno določene značilnosti, ki se nanašajo na preverljive pretekle dosežke in izkušnje mladih ter pomenijo pomembno vsebinsko informacijo:

- starost;

- izobraževalne izkušnje;

- delovne izkušnje;

- status;

- izbira mladih, ki so se šolali po splošnih programih oziroma niso bili kakorkoli kate- gorizirani (mladi s posebnimi potrebami ali mladi, ki jim ni bil izrečen vzgojni ukrep).

2. Individualno in kulturno pogojene značilnosti, ki jih lahko le predpostavljamo in jih $\mathrm{v}$ programu opredeljujemo kot funkcionalne vedenjske cilje, ki naj bi bile le vodilo pri izvedbenem načrtovanju:

- manjša motiviranost za izobraževanje, še zlasti kot šolske oblike posredovanja znanja;

- negativni učinki družbene izoliranosti (strategije, ki zadovoljujejo princip ugodja, in izmikanje principu realnosti - uživanje mamil, alkoholizem, ilegalizem, nasilniško vedenje; nemotiviranost za družbeno participacijo in neartikuliranost interesnih področij);

- pomanjkljiva artikuliranost poklicno interesnega področja;

- pomanjkanje pragmatičnih izkušenj v vsakdanjih življenjskih okoliščinah in pomanjkljiva praktična družbena informiranost;

- pomanjkanje funkcionalnih socialnih spretnosti za uspešno komunikacijo $\mathrm{v}$ manjših skupinah in vključevanje $\mathrm{v}$ širšo družbeno skupnost.

Navedene kategorije vsekakor pomenijo le izhodiščni opis in zahtevajo širšo vsebinsko 
razčlenitev, ki pa jo bomo predstavili ob drugi priložnosti, morda $v$ enem izmed prihodnjih prispevkov. Prav tako pa šele prvi korak, ki nam $v$ nadaljevanju omogoči definicijo ciljev izobraževalnega programa. Pri tem ostajajo nerešena temeljna vprašanja, ki jih - kot izziv za razvoj kurikularnega načrtovanja izobraževalnih programov za mlade in kot napoved predstavitve rezultatov naših raziskovanj na Andragoškem centru - navajamo v zgoščeni obliki problemske postavitve: kaj pogojuje določitev temeljnih izobraževalnih ciljev. Kaj je temeljno znanje, ki omogoča subjektom avtonomno družbeno ravnanje? Ali potrebujejo mladi v dobi ekspanzije informacijskih tehnologij za preživetje pismenost, praktičnost ali povsem druge spretnosti in druge vrste znanja? Katere oblike pedagoške tehnologije vodijo $\mathrm{k}$ učinkom fleksibilnosti za zahteve sodobnega, storitveno naravnanega delovnega trga?

\section{LITERATURA}

Bela knjiga o vzgoji in izobraževanju v Republiki Sloveniji. (1995). Ljubljana: Ministrstvo RS za šolstvo in šport.

Coleman, J.S. (1994). Social capital, human capital, and investment in youth. v: Petersen; Mortimer. (1994). Youth unemployment and Society. Cambridge: CUP.

Davidson, Howard, S. (1995). Making needs: Toward a historical sociology of needs in adult and continuing education. Adult Education Quarterly, 45 (1995) 4, 183196.

Durkheim, Emile. (Š1897] 1992). Samomor. Ljubljana: Studia Humanitatis.

Ekinsmyth, Carol; Bynner, John. (1994). The Basic Skills of Young Adults. London: ALBSU.

European Commission. (1995). Employment in Europe. Office for Official Publications of the European Comunities: Luxembourg.

Evans, Glen; Poole, Millicent. (1991). Young Adults. Self Perceptions and Life Contexts. London, New York: The Falmer Press.

Frosh, Stephen. (1991). Identity Crisis. Modernity, Psychoanalysis and the Self. London: Macmillan.

Gillis, John R. (1993). Vanishing youth: The uncertain place of the young in a global age. Young - Nordic Journal of Youth Research 1(1993)1, 3-17.

Janko, Alenka. (1997). Izobraževanje in strategije pismenosti. (magistrsko delo) Ljubljana: Filozofska fakulteta, oddelek za sociologijo.

Kallen, Denis (1996). Srednješolsko izobraževanje: prikladen koncept. Poročilo konference Sveta Evrope, Strasbourg (2.-5. 12. 1996).

Ketter, Per-Marcel; Hans Joachim Petzold; Wolfgang Schlegel. (1987). Training for everyone: a guide to the planning of inovative training and employment projects for unemployed young people in the European Community. Berlin: CEDEFOP.

Köditz, Volker. (1981). Youth unemployment and vocational training. The material and social standing of young people during transition from school to working life. (Synthesis report). Berlin: CEDEFOP.

Kraigher, Tomaž. (1994). Prebivalstvo in zaposlenost v Sloveniji na prehodu iz osemdesetih v devetdeseta leta in ocene tendenc razvoja do leta 2000 (delovni zvezek). Ljubljana: Zavod RS za makroekonomske analize in razvoj.

Močnik, Rastko. (1985). Beseda besedo. Ljubljana: ŠKUC.

Mrgole, Albert; Žalec, Natalija. (1996a). Poročilo 1. faze evalvacije eksperimentalnega projekta $\mathrm{CMO}$. Ljubljana: ACS.

Mrgole, Albert; Žalec, Natalija. (1996b). Poročilo 2. faze evalvacije eksperimentalnega projekta CMO. Ljubljana: ACS.

Mrgole, Albert. (1996c). Premagovanje izoliranosti, ki jo povzroča brezposelnost. (Izobraževanje ali sociala - novi pristopi v izobraževanju mladih brezposelnih). Delo, Priloga: Znanost za razvoj, 2. 10. 1996, s. 11.

Mrgole, Albert. (1996d). Poročilo 3. faze evalvacije eksperimentalnega projekta CMO. Ljubljana: ACS.

Mrgole, Albert. (1996e). Razvoj kurikuluma za mlajše odrasle na prehodu iz osnovnega v poklicno izobraževanje (raziskovalno poročilo). Ljubljana: ACS.

Mrgole, Albert. (1997). K teoriji mladinske brezposelnosti. Andragoška spoznanja, 1 (1997), 13-19.

Petersen, Anne C.; Mortimer, Jeylan T. (ed.). (1994). Youth Unemployment and Society. Cambridge: Cambridge University Press.

Pye, D.; Haywood, C.; Mac an Ghaill, M. (1996). The Training State, De-industrialisation and the Production of White Working-class Trainee Identities. v: International Studies in Sociology of Education 6 (1996) 2, 133146.

Rosenbaum, James E.; Binder, Amy. (1997). Do Employers Really Need More Educated Youth? v: Sociology of Education 70 (1997): 68-85.

Scott, Sally. (1996). Education and Training Programmes for Young Unemployment People in the UK, Dennmark and Slovenia. Dissertation for the Masters Degree. University of Bath.

Ule, Mirjana; Miheljak, Vlado. (1995a). Pri(e)hodnost mladine. Ljubljana: DZS.

Ule, Mirjana. (1995b). Psihosocialne značilnosti mlajših odraslih. Program usposabljanja učiteljev za izvajanje programa UŽU. Ljubljana: (interno gradivo ACS).

Ule, Mirjana Nastran (ur.). (1996a). Mladina v devetdesetih. Analiza stanja v Sloveniji. Ljubljana: Znanstveno in publicistično središče.

Ule, Mirjana Nastran (ur.). (1996b). Predah za študentsko mladino. Ljubljana: Urad RS za mladino, Zavod RS za šolstvo.

Young people in transition - the local investment. (1986). Berlin: CEDEFOP.

Zakrajšek, Srečo. (1995). Slovensko šolstvo v tranziciji. Ljubljana: Biteks.

Žalec, Natalija; Krajnc, Ana. (1994). Vzgojnoizobraževalni program centrov za mlajše odrasle v Sloveniji (mapa). Ljubljana: Andragoški center Sløvenije. 